\title{
Changing the prehistory of Sindh and Las Bela coast: twenty-five years of Italian contribution
}

\author{
Paolo Biagi
}

\begin{abstract}
This paper discusses the prehistory of Sindh and Las Bela coast (Balochistan) before and after partition, and the role played by the Italian archaeologists since the 1980s. Until a few years ago the prehistory of Sindh was known mainly from the impressive urban remains of the Indus civilization and the discovery of Palaeolithic assemblages in the desert landscapes close to India, while very little was known of the remains of other periods, their radiocarbon dating and the importance of the coastal zone. Our knowledge of the prehistory of the country has improved greatly during the last twenty-five years, thanks to systematic surveys and excavations in unexplored landscapes, which radically transformed our knowledge of the prehistoric archaeology of this important region of the Indian subcontinent.
\end{abstract}

\section{Keywords}

Sindh; Indus delta; Arabian Sea; raw material sources; shell middens; radiocarbon chronology.

\section{Introduction}

On 20 September 1924, Sir John Marshall announced that 'an entirely new culture going back to Chalcolithic epoch came to light in the Indus valley, in Sindh near Larkana' (Childe 1926: 34), where the urban remains of Mohenjo-daro gave the visitor 'an impression of a democratic bourgeoise economy' (Childe 1934: 207).

The excavations carried out by Marshall (1931), Mackay (1937-8), Wheeler (1976; Ray 2008) and others (Lahiri 2005: 205) brought to light the remains of a complex metropolis (Dikshit 1939), with public and private structures, craftsmen quarters, a 'distinct lack of evidence of warfare' (Possehl 1997: 434), few metal implements, where 'flint and stone tools are represented only by a few quite simple blades and a few large chert tools flaked

Routledge

Taylor \& Francis Group
World Archaeology Vol. 43(4): 523-537 Debates in World Archaeology

(C) 2011 Taylor \& Francis ISSN 0043-8243 print/1470-1375 online

http://dx.doi.org/10.1080/00438243.2011.624695 
like celts' (Childe 1934: 217), which was immediately supposed to indicate trade with the Arabian peninsula (Childe 1928: 214).

Between 1927 and 1931 Majumdar carried out intensive surveys in Sindh (Majumdar 1981), thanks to which new Bronze and Copper Age sites were discovered. He surveyed also the Indus delta, where he revisited the Tharro Hills (Piggott 1950: 79), discovered by G. E. L. Carter just a few years before (Cousens 1998: 38) and, along the course of the Indus, Amri (Burnes 1834: 58; Casal 1964) and Ghazi Shah (Flam 1996, 2006). Further investigations were carried out by Lambrick in the 1940s (Lambrick 1986).

\section{The 1985-2010 surveys and excavations}

\section{The chippable raw material sources}

Until the end of the 1980s very little was known of the distribution of the chippable raw material sources in Sindh. The first flint workshops were discovered in the 1880 s on the Rohri Hills, near Rohri, in Upper Sindh (Evans 1886), although their cultural attribution was defined only some fifty years later (de Terra and Paterson 1939). Following the surveys of the Cambridge Archaeological Mission, Allchin (1979) wrote a report on the Holocene blade assemblages of Sindh. A decade later a paper by Cleland (1987) pointed out the scarcity of data available for the Holocene chipped-stone industries of the Indus Valley, especially those of Amri, Kot Diji and Indus periods.

The surveys and excavations carried out between 1985 and 2002 in the Rohri Hills led to the discovery of impressive flint-mining complexes of the Mature Indus Civilization (Biagi and Cremaschi 1991; Biagi et al. 1997) (Plate 1). A few test trenches were opened, and some workshops excavated, among which are Sites 58 and 59 (Biagi and Pessina 1994), 480 (Negrino and Starnini 1995), 862 (radiocarbon-dated to $3870 \pm 70$ BP (GrA-3235)) (Biagi 1995; Negrino et al. 1996; Starnini and Biagi 2006) and ZPS3 (Negrino and Starnini 1996). Nevertheless, most archaeologists underestimated the importance of this raw material (Kenoyer 1991; Lahiri 1992), which always played a very important role in the economy of the Indus people, as the research in the Rohri Hills (Biagi and Starnini 2008) and the craftsmen quarters of Mohenjo-daro had shown (Tosi et al. 1984; Vidale 1992, 2000). In 2000 the Italian Archaeological Mission launched a programme of surveys in Lower Sindh. The limestone terraces of Ongar, Daphro and Bekhain, south of Kotri, revealed Indus flint-mining trenches and workshops identical to those of the Rohri Hills (Biagi 2007a; Biagi and Franco 2008).

The 2010-11 surveys, extended to Jhimpir, led to the discovery of good quality flint sources also in this region. They had been first exploited by Final Palaeolithic huntergatherers and later mined most probably during the Chalcolithic (Biagi and Nisbet 2010).

The Late (Upper) Palaeolithic and Mesolithic sites discovered by Khan (1979a) around Karachi and Rehri, and the shell middens of Las Bela coast (Biagi 2004, 2008a), yielded chipped-stone assemblages obtained from small alluvial pebbles, and liver-coloured Gadani jasper (Snead 1969), a source exploited until the Bronze Age, as shown by a radiocarbon result (GrN-26369: $4460 \pm 30$ BP). In his report on Allahdino, Fairservis (1982) mentions another good quality flint source some $5 \mathrm{~km}$ east of Karachi (Hoffman and Cleland 1977). 


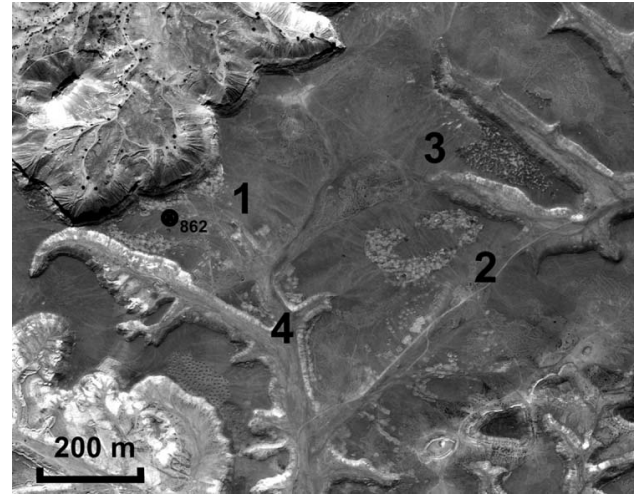

Plate 1 Rohri Hills: groups of Indus flint mines (1-4) on the mesas east of the shrine of Shadee Shaheed, with the indication of the excavated Site 862 (dot).

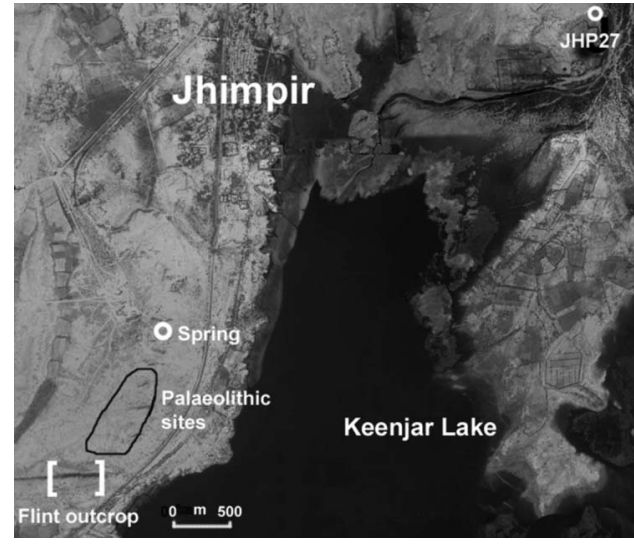

Plate 2 Jhimpir: distribution map of the Final Palaeolithic find spots, on the limestone terraces facing the present-day shore of Keenjar Lake, between a freshwater spring, in the north, and a flint source, in the south. JHP27 locates a microbladelet flint core (map by P. Biagi).

According to these data, and contrary to what was supposed until a few years ago, both Sindh and Balochistan (Aubry et al. 1988; Law et al. 2002-3) are rich in chippable stone sources, a few artefacts from which were traded down to the Arabian Sea and Gujarat in Mature Indus times (Baloch 1973; Biagi 2004: 9; Rao 1985: 558).

\section{The Late (Upper) Palaeolithic and Mesolithic sites}

Before the 1970s Palaeolithic sites had been discovered only on the Rohri Hills and Ongar (Allchin 1976; Allchin et al. 1978), with the exception of two assemblages with geometric microliths from Lower Sindh (Gordon 1950; Todd and Paterson 1947).

The surveys carried out by Professor Khan in the 1970s yielded an impressive number of sites in the surroundings of Karachi. They can be grouped into three main complexes, the first of which belongs to the Late (Upper) Palaeolithic, the other two to the Mesolithic (Khan 1979b). The three periods are characterized by a) various types of burins, thick curved backed points obtained by bipolar retouch, backed bladelets and microbladelets, rare lunates and truncations, b) many lunates, obtained by abrupt, direct or bipolar retouch and c) varieties of trapezoidal armatures, mainly isosceles, pointed or transversal and, in a few cases, notched flakelets. This subdivision cannot be applied to the industries from the Thar Desert, most of which can be attributed to the Atlantic period because of specific types of isosceles trapezes (Biagi 2003-4, 2008b). In 2010 Final Palaeolithic tools were collected also from Jhimpir and Ranikot (Biagi 2011) (Plate 2).

These discoveries demonstrate that Late (Upper) Palaeolithic and Mesolithic huntergatherers inhabited both Upper and Lower Sindh. So far their chronology cannot be ascertained because of the absence of stratigraphic sequences and organic material, although their cultural attribution can be suggested thanks to the presence of specific tool types. 
The shell middens of Las Bela coast

The first shell middens were discovered in the Daun Bay, south of Gadani promontory, in January 2000 (Biagi 2004). In 2004 more middens were recorded on the high marine terrace immediately south of the same bay (Snead 1969), and also below the above terrace, in January 2008 (Biagi and Franco 2008). The sites (Plate 3), mainly composed of fragmented Terebralia palustris mangrove shells with very few material culture remains, are grouped in well-defined clusters (Plate 4). Their absolute date varies also according to their location. From a chronological point of view, they seem to group in two main

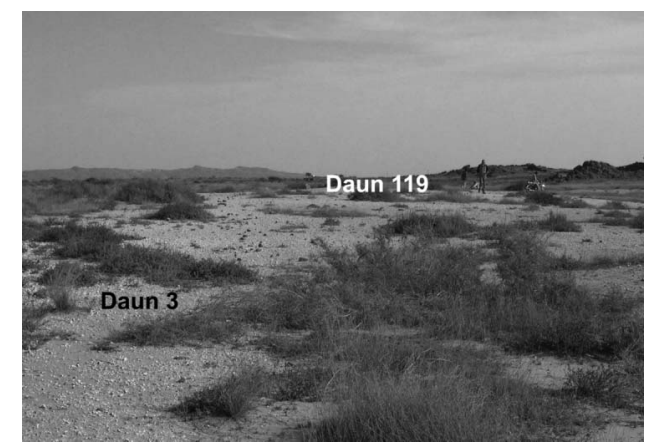

Plate 3 Daun: the shell middens Daun 3 and Daun 119 (photo: P. Biagi).

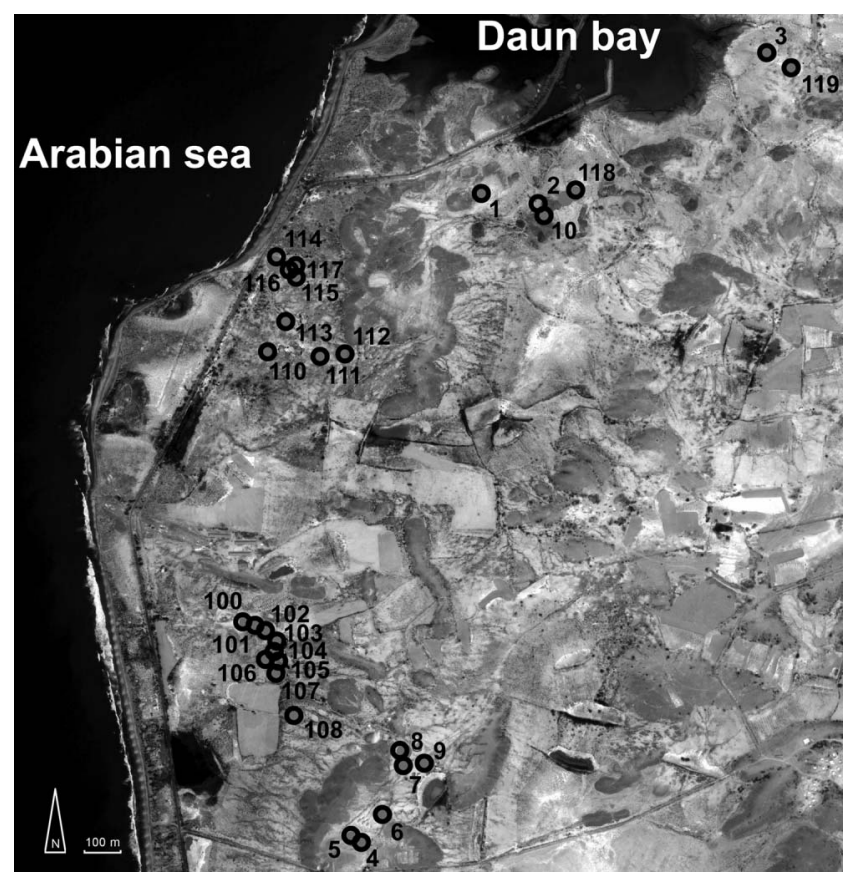

Plate 4 Daun: distribution map of the shell middens discovered between 2000 and 2008 (original map by C. Franco). 
clusters, the first of the seventh, the second of roughly the first half of the fifth millennium BP (Plate 5 and Table 1).

Apart from an isolated case in Iranian Makran (Vita-Finzi and Copeland 1980), the Daun shell middens represent the thickest concentration of such sites so far known along the Balochi coast of the northern Arabian Sea, given that no sites of this type have ever been recovered during the preceding surveys (Besenval and Sanlaville 1990; Dales and Lipo 1992; Desse and Desse-Berset 2005; Snead 1967). Scatters of mangrove shells are reported by Snead (1966: 118) from the eastern shore of Siranda lake, along the shores of which Terebralia palustris, Telescopium telescopium and Arcidae shell middens were recorded in January 2011. A different shell midden, rich in net sinkers, was discovered on a high terrace of the Upper Nari formation at Sonari (Khan 1979c), close to the Hab River mouth. It was radiocarbon dated to $4080 \pm 30$ BP $(\mathrm{GrN}-27054)$.

\section{The Indus Delta}

This region is essential to understanding the advance of the northern coastline of the Arabian Sea and the formation of the Indus lower plain (Giosan et al. 2006; Harvey and Schumm 1999; Inam et al. 2007; Wilhelmy 1968).

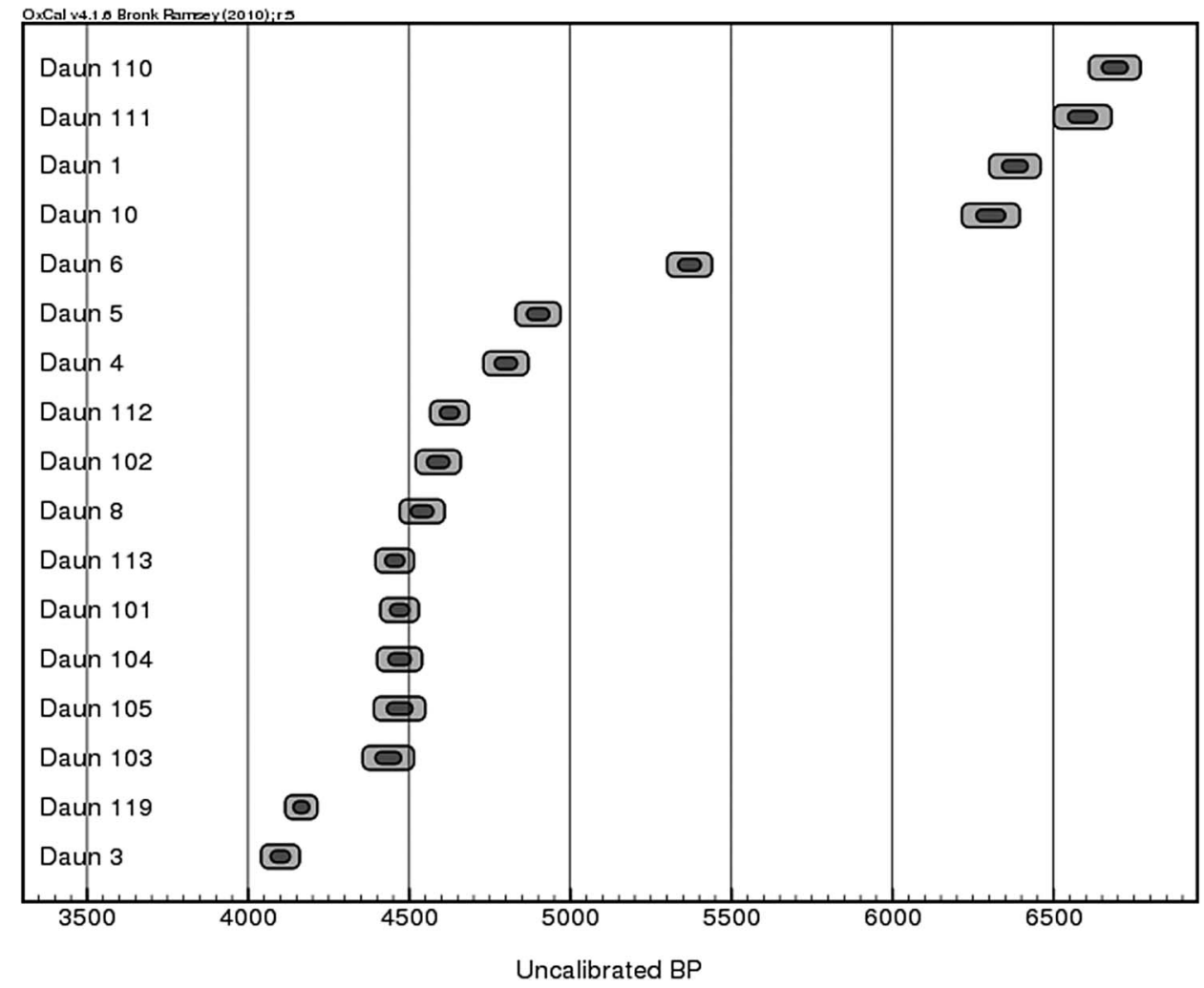

Plate 5 Daun: plot of the uncalibrated radiocarbon dates of Table 1 (courtesy of T. Fantuzzi). 
Table 1 Radiocarbon dates from mangrove and marine shells obtained from the coastal sites of Lower Sindh and Las Bela, mentioned in the text. Calibration applied a $\Delta \mathrm{R}$ of $229 \pm 27$ years (Dutta et al. 2001; Reimer and Reimer 2001)

\begin{tabular}{|c|c|c|c|c|c|c|}
\hline te name & Coordinates & Material & Lab number & $\delta^{13} \mathrm{C}$ & Age $B P$ & Cal. BC $2 \sigma$ \\
\hline & $\mathrm{E}$ & & & & & \\
\hline & & & & & & \\
\hline & & & & & & \\
\hline & & & & & & \\
\hline & & & & & & \\
\hline & & Terebralia $p$. & & & & 2861 \\
\hline & & & & $-5,3$ & & 671 \\
\hline In 112 & & ebralia p. & & $-4,95$ & & \\
\hline aun 1 & $-66^{\circ} 42^{\prime} 21^{\prime \prime} \mathrm{E}$ & ia $p$. & & 5,96 & & \\
\hline & & & & 5,16 & & \\
\hline & & & & & & \\
\hline & & & & & & \\
\hline & & & & & & \\
\hline & & & & & & \\
\hline & & lia $p$. & & & & \\
\hline & & & & & & \\
\hline & & lia $p$. & & $-4,49$ & & 752 \\
\hline & & & & & & \\
\hline & & & & $-4,9$ & & \\
\hline & & & & & & \\
\hline & $4^{\prime \prime} \mathrm{E}$ & & & & & \\
\hline & & & & $-0,11$ & & \\
\hline KKT 2 & $23^{\prime \prime} \mathrm{E}$ & Terebralia $p$ & & $-5,5$ & & 4442 \\
\hline & $7^{\circ} 45^{\prime} 09^{\prime \prime} \mathrm{E}$ & Terebralia $p$ & & $-6,9$ & & 041 \\
\hline & ${ }^{\circ} 43^{\prime} 46^{\prime \prime} \mathrm{N}-67^{\circ} 45^{\prime} 07^{\prime \prime} \mathrm{E}$ & ebralia p. & & $-5,15$ & & 3635 \\
\hline & & & & & & \\
\hline & & & & & & \\
\hline & & Terebralia $p$ & & & & \\
\hline & & Telescopium $t$. & & $-3,21$ & & $2231-1926$ \\
\hline OBS 1 & $24^{\circ} 22^{\prime} 18^{\prime \prime} \mathrm{N}-67^{\circ} 58^{\prime} 21^{\prime \prime} \mathrm{E}$ & Terebralia p. & GrA-47082 & $-9,17$ & $3790 \pm 35$ & $1619-1396$ \\
\hline
\end{tabular}

At the time of Alexander's invasion $(327 \mathrm{BC})$ 'the sea extended up to Gujo area' (Panhwar 1964: 100), a boundary generally accepted by both geologists (Bender 1995: fig. 10.18) and historians (Eggermont 1975: map 2). The Indus coastal landscape of the first century $\mathrm{AD}$ is accurately described in The Periplus of the Erythraean Sea: 'the river has seven mouths, very shallow and marshy, so that they are not navigable, except the one in the middle; at which by the shore, is the market town, Barbaricum. Before it lies a small island, and inland behind it is the metropolis of Scythia, Minnagara' (Schoff 1974: 37).

This problem has been reconsidered by Flam (1984, 1987), while Blandford, in his geological study of Thatta district, reports:

to the west of Makli Hill there are several small scattered rises in the alluvium; all, except one, which is Khirtar, composed of Nari beds. Farther west, and again to the 
south-west, there are some detached rocky rises of peculiar formation, ascribed to the Gáj group.

(Blandford 1880: 154)

A third range of high ground occurs close to Tatta, and is 18 miles long from north to south and 4 from east to west. In all these cases portions are detached and separated by alluvium from the main range, and there are some other small and unimportant patches, none of which are of any size, near the edge of the alluvial area.

(Blandford 1880: 24)

Most authors believe that the above 'rocky rises' were islands in Hellenistic times. For instance, according to Piggott (1950: 77) and Khan (1979a: 5), the Tharro Hills were an island close to the northern coastline in Chalcolithic times. This opinion is supported by two radiocarbon dates from marine and mangrove shells ( GrN-27053, $5240 \pm 40$ BP, for THR1; GrA-47084, $5555 \pm 35$ BP, for THR3). Another date (GrN-32119, $6910 \pm 60$ BP, for THR2), from a small scatter of Ostreidae, shows that the hills were first settled during the Neolithic (Plate 6).

The 2009-10 surveys led to the discovery of archaeological finds from most of the above rocky outcrops, a few of which were radiocarbon dated (Biagi 2010). They are:

1. Beri: a boat-shaped limestone terrace, some $1.6 \mathrm{~km}$ south-east of the Tharro Hills (Lambrick 1942: 110; Romm 2010: 255). Its surface is covered with

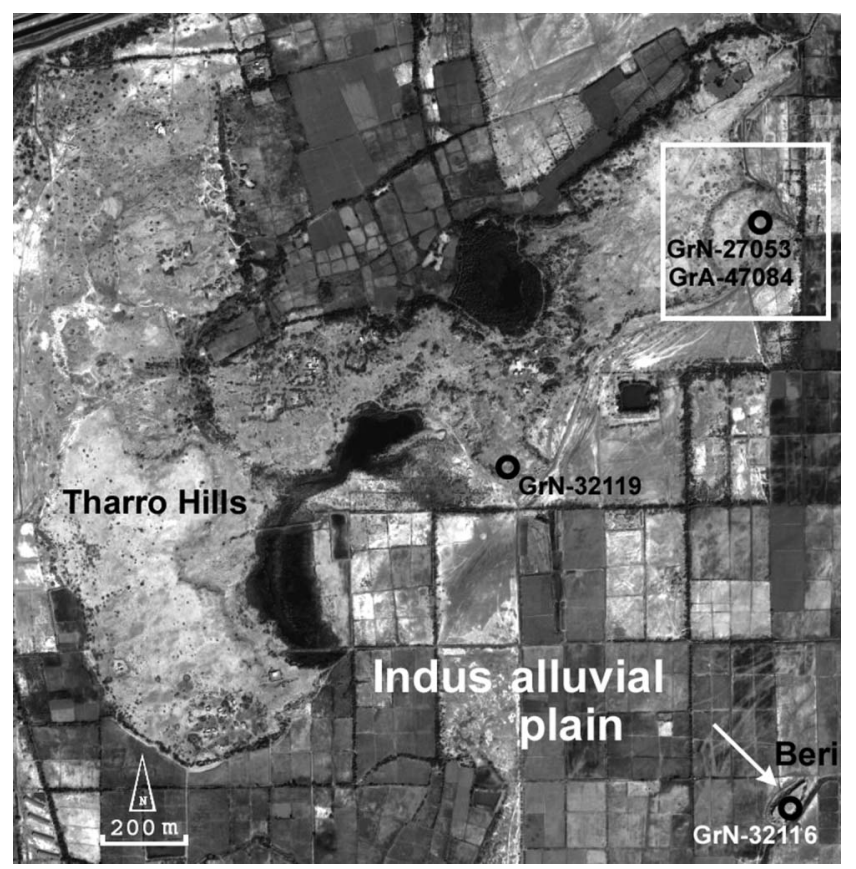

Plate 6 Tharro Hills and Beri: distribution map of the radiocarbon-dated sites. The Amri culture settlement is marked by the white square (map by C. Franco and P. Biagi). 
mangrove and marine shells, flint artefacts and potsherds. One specimen of Terebralia palustris mangrove gastropods has been radiocarbon-dated to $5960 \pm 50$ BP (GrN-32116).

2. Jabal Shah Husein: a hillock some $850 \mathrm{~m}$ long and $350 \mathrm{~m}$ wide, $c .12 \mathrm{~km}$ south of the Tharro Hills and $1 \mathrm{~km}$ west of the Makli Hills. Mangrove and marine shells, mainly Ostreidae, were recovered from seven spots, two of which were radiocarbon-dated to $5325 \pm 40$ BP (GrA-45180: JSH1) and $4245 \pm 40$ BP (GrA-45181: JSH2).

3. Makli Hills: three scatters of Terebralia palustris shells and very few flint artefacts were found close to the sixteenth-century AD fortress of Kalan Kot (Cousens 1998: 98). One yielded the radiocarbon result of $6320 \pm 45$ BP (GrN-32464: KKT2).

4. Oban Shah: these rocky outcrops were called 'the island in the sea' by Arrian (Robson 1967). A very few mangrove and marine shells come from two different spots, one of which was dated to $3790 \pm 35$ BP (GrA-47082: OBS1).

One more Terebralia palustris fragment from Kot Raja Manjera (Biagi 2010; Khan 1979a: 6) was radiocarbon-dated to $4635 \pm 35$ BP (GrA-47083: KRM13).

The new radiocarbon results can help define 1) the seafaring activities of the earliest inhabitants of this part of the northern coast of the Arabian Sea, 2) the development of the Indus plain, 3) the variation of the ancient coastline and 4) the distribution of the ancient mangroves and their exploitation by prehistoric communities.

\section{Discussion}

The main achievement of the archaeological research in Sindh during the British period was the discovery of new Copper and Bronze Age sites. Extensive excavations were carried out at some of the most impressive sites, thanks to which it was also possible to suggest relationships with other neighbouring aspects of the third millennium cal. BC. The Amri, Nal, Kot Diji and Kulli cultures were also defined in this period (Wheeler 1950).

The main changes that occurred after partition, and especially after the 1970s, regard:

1. Some aspects of the Indus economic system The Italian contribution was centred on the study of the craftsmen quarters and the HR area of Mohenjo-daro (Leonardi 1988; Tosi et al. 1984) and the flint mines of the Rohri Hills (Biagi and Cremaschi 1991). One of the peculiarities of the Indus civilization consists in the everyday use of flint tools instead of metal implements, just the opposite of what one would expect from a Bronze Age civilization. The study of the bead-making and ceramic workshops of Mohenjo-daro (Halim and Vidale 1984; Pracchia et al. 1985) pointed out the importance of flint, its procurement from the Rohri Hills sources, its technology and the way it was utilized by the city craftsmen.

The Rohri Hills revealed the complexity of the Indus mining centres, for example those of the Shadee Shaheed Hills (Plate 1), which yielded more than 2,000 flint mines and workshops (Maifreni 1995). Thanks to their study it was possible to interpret the way they had been excavated, the varieties of flint available from different regions of the hills in different Bronze Age periods, and to point out the 
importance of the lithic resources for the Indus people, which contrasted with the very limited data available before the 1980 s.

2. The Palaeolithic and Mesolithic The study of the lithic assemblages collected by Khan in the 1970s, the excavation of Palaeolithic workshops at Ziarat Pir Shaban in the Rohri Hills (Biagi et al. 1996; 1998-2000), the discovery of typical Levalloisian assemblages at Ongar (Biagi 2007b; Biagi and Starnini 2011) and of Mesolithic sites in the Thar Desert (Biagi 2003-4; 2008b) drastically changed our view of the earliest periods of the prehistory of Sindh. Until 2000 nothing was known of the Mesolithic of the study region, the landscapes settled by the last hunter-gatherers of the early Holocene and the characteristics of their chipped-stone assemblages. This was due to the absence of any professional, systematic survey in most of Sindh. In contrast, at present it is clear that the Early, Middle and Late (Upper) Palaeolithic periods are represented by characteristic assemblages with well-defined lithic types (Biagi 2008c), and that Mesolithic bands settled close to freshwater springs and chippable raw material sources, inhabiting coastal zones, river banks and desert sand dunes close to lake shores. At present, dozens of sites of this period are known, which makes the Mesolithic prehistory of Sindh one of the richest of the Indian subcontinent.

3. The prehistoric settlement of the northern Arabian Sea coast and their chronology The surveys carried out along the coast of Las Bela and the Indus delta revealed the great archaeological potential of both these territories. The radiocarbon dates from Daun shell middens show that, similarly to what was already known from the coasts of the Persian Gulf and the Arabian Peninsula (Biagi 2008a; Cleuziou 2004; Lambeck 1996; Sanlaville and Dalongeville 2005; Stein 1943), the northern coastline of the Arabian Sea also started to be inhabited around the beginning of the seventh millennium BP, and some kind of seafaring activity led to the earliest settling of the islets at present surrounded by Indus delta alluvium (Biagi 2010) (Plate 7).

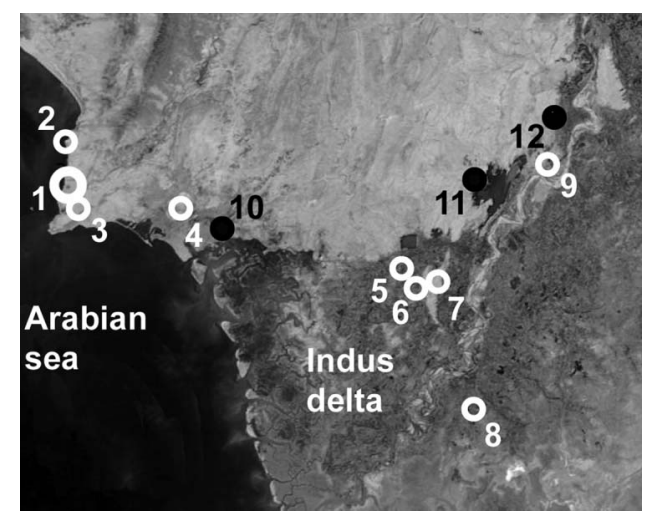

Plate 7 Lower Sindh: distribution map of the sites mentioned in the text: 1) Daun, 2) Gadani, 3) Sonari and Pir Shah Jurio (PSJ), 4) Mulri Hills 18 (MH18), 5) Tharro Hills and Beri, 6) Jamal Shah Husein (JSH), 7) Kalan Kot (KKT), 8) Oban Shah (OBS), 9) Kot Raja Manjera (KRM13), 10) Rehri, 11) Jhimpir, 12) Ongar, Daphro and Bekhain. The radiocarbon-dated sites are marked by a white circle (map by P. Biagi). 
The radiocarbon results, mainly from specimens of Terebralia palustris mangrove gastropods (Table 1), show that the coastline was farther north, up to Kot Raja Manjera, during the Bronze Age, and that it advanced down to the 'Island in the Sea', present-day Oban Shah (Eggermont 1975: 30), some one millennium later. Although research in the Indus delta is still under way and the available radiocarbon dates are few, they show that people moved across this part of the Indian Ocean in different periods of prehistory, at least since the beginning of the Neolithic, and exploited both marine and mangrove environments. They also tell us that Early Neolithic communities roughly contemporary with those from Mehrgarh (Jarrige 2004) were also active in the region.

To conclude, in light of the new discoveries, the Holocene prehistory of this part of Sindh, of which almost nothing was known until a few years ago (see, for instance, Allchin and Allchin 1982, 1997; Possehl 2002), needs to be urgently and totally revised.

\title{
Acknowledgements
}

The author is very grateful to all the people and institutions that made the research in Sindh possible, mainly Mir Atta Mohammad Talpur, Mir Ghulam Rasool Talpur, Mir Ahmed Farooq Talpur, Mir Abdul Rehman Talpur; the former Vice-chancellor of Sindh University, Professor Mazharul Haq Siddiqui, and the former Director of the Institute of Sindhology, Mr Shoukat Shoro; all the members of the Joint Rohri Hills Project; Dr M. Spataro (British Museum, London), Professors F. Pontani and R. Nisbet, Dr C. Franco and Mr T. Fantuzzi (Ca' Foscari University, Venice); and Professors A. R. Khan and B. Talat (Department of Geography, Karachi University). Special thanks are due to Drs A. and S. Gnutti of Gnutti EURAL (Rovato, Brescia), the Italian Ministry of Foreign Affairs (MAE), the National Geographic Society (Washington), the Prehistoric Society (London), Professor G. Traversari and the CeVeSCO (Ca' Foscari University, Venice) and the Ligabue Foundation (Venice) that sponsored and financed the archaeological research in Sindh.

\author{
Ca’ Foscari University, Venice, Italy \\ pavelius@unive.it
}

\section{References}

Allchin, B. 1976. Palaeolithic sites in the plains of Sind and their geographical implications. The Geographical Journal, 142(3): 471-89.

Allchin, B. 1979. Stone blade industries of early settlements in Sind as indicators of geographical and socio-economic change. In South Asian Archaeology 1977 (ed. M. Taddei). Seminario di Studi Asiatici, Series Minor, 6 Naples: Istituto Universitario Orientale, pp. 173-211.

Allchin, B. and Allchin, R. 1982. The Rise of Civilization in India and Pakistan. Cambridge: Cambridge University Press.

Allchin, R. and Allchin, B. 1997. Origins of a Civilization: The Prehistory and Early Archaeology of South Asia. New Delhi: Viking.

Allchin, B., Goudie, A. and Hedge, K. 1978. The Prehistory and Palaeogeography of the Great Indian Desert. New York, San Francisco and London: Academic Press. 
Aubry, T., Zulfiquar, A. and Khan, M. B. 1988. A preliminary study of cherts from Balochistan. Acta Mineralogica Pakistanica, 4: 102-12.

Baloch, N. A. 1973. In search of the Indus culture sites in Sind. Bulletin of the Institute of Sindhology University of Sind, 3(2-3): 11-32.

Bender, H. 1995. Water. In Geology of Pakistan (eds F. K. Bender and A. Raza). Beiträge zur Regionalen Geologie der Erde, 25. Berlin and Stuttgart: Gebrüder Borntraeger, pp. 291-328.

Besenval, R. and Sanlaville, P. 1990. Cartography of ancient settlements in Central Southern Pakistani Makran: new data. Mesopotamia, 25: 79-146.

Biagi, P. 1995. An AMS radiocarbon date from the Harappan quarry-pit 862 in the Rohri Hills (Sindh - Pakistan). Ancient Sindh, 2: 81-84.

Biagi, P. 2003-4. The Mesolithic settlement of Sindh (Pakistan): a preliminary assessment. Praehistoria, 4-5: 195-220.

Biagi, P. 2004. New radiocarbon dates for the prehistory of the Arabian Sea coasts of Lower Sindh and Las Bela in Balochistan (Pakistan). Rivista di Archeologia, 28: 5-16.

Biagi, P. 2007a. Quarries in Harappa. In Encyclopaedia of the History of Science, Technology, and Medicine in Non-Western Cultures, Vol. 2 (ed. H. Selin). Berlin and Heidelberg: Springer, pp. 1856-1863.

Biagi, P. 2007b. The Levalloisian assemblages of Sindh (Pakistan) and their importance in the Middle Palaeolithic of the Indian subcontinent. In Archaeology of Northeastern Africa (eds K. Kroeper, M. Chłodnicki and M. Kobusiewicz). Studies in African Archaeology, 9: 1005-17.

Biagi, P. 2008a. The shell-middens of the Arabian Sea and Gulf: maritime connections in the seventh millennium BP? In The City in the Arab World in Light of Archaeological Discoveries: Evolution and Development (eds A. R. Al-Ansary, K. I. Al-Muaikel and A. M. Alsharek). Riyadh: Abdul Rahman Al-sudairy Foundation, pp. 7-16.

Biagi, P. 2008b. New discoveries of Mesolithic sites in the Thar Desert (Upper Sindh, Pakistan). In Intercultural Relations between South and Southwest Asia: Studies in Commemoration of E.C.L. During Caspers (1934-1966) (eds E. Olijdam and R. H. Spoor). Oxford: BAR International Series, 1828, pp. 78-85.

Biagi, P. 2008c. The Palaeolithic settlement of Sindh (Pakistan): a review. Archäologische Mitteilungen aus Iran und Turan, 40: 1-26.

Biagi, P. 2010. Archaeological surveys in Lower Sindh: preliminary results of the 2009 season. Journal of Asian Civilizations, 33(1): 1-42.

Biagi, P. 2011. Late (Upper) Palaeolithic sites at Jhimpir in Lower Sindh (Thatta, Pakistan). In Studies in Honour of Is sin Yalçınkaya (eds M. Kartal, H. Taşkiran, K. Özcelik, M. B. Kösem and G. Kartal). Ankara: Bilgin Kültür Sanat Yayinlari, pp. 67-84.

Biagi, P. and Cremaschi, M. 1991. The Harappan flint quarries of the Rohri Hills (Sindh, Pakistan). Antiquity, 65(246): 97-102.

Biagi, P. and Franco, C. 2008. Ricerche archeologiche in Balochistan e nel Sindh Meridionale (Pakistan). In Missioni Archeologiche e Progetti di Ricerca e Scavo dell'Università Ca' Foscari Venezia (ed. S. Gelichi). Rome: Bretschneider, pp. 9-18.

Biagi, P. and Nisbet, R. 2010. The prehistoric flint mines at Jhimpir in Lower Sindh (Pakistan). Antiquity Project Gallery, 84 (235). Available at: http://antiquity.ac.uk/projgall/nisbet325/

Biagi, P. and Pessina, A. 1994. Surveys and excavations in the Rohri Hills (Sindh-Pakistan): a preliminary report on the 1993 campaign. Ancient Sindh, 1: 13-75.

Biagi, P. and Starnini, E. 2008. The Bronze Age Indus quarries of the Rohri hills and Ongar in Sindh (Pakistan). In Geoarchaeology and Archaeomineralogy (eds R. I. Kostov, B. Gaydarska and M. Gurova). Sofia: St. Ivan Rilski, pp. 77-82. 
Biagi, P. and Starnini, E. 2011. Neanderthals at the south-easternmost edge: the spread of Levalloisian Mousterian in the Indian subcontinent. In Papers in honour of Viola T. Dobosi (eds K. T. Biró and M. András). Budapest: Hungarian National Museum, pp. 5-14.

Biagi, P., Kazi, M. M. and Negrino, F. 1996. An Acheulian workshop at Ziarat Pir Shaban on the Rohri Hills, Sindh, Pakistan. South Asian Studies, 12: 49-62.

Biagi, P., Negrino, F. and Starnini, E. 1997. New data on the Harappan flint quarries of the Rohri Hills (Sindh - Pakistan). In Man and Flint: Proceedings of the VIIth International Flint Symposium (eds R. Schild and Z. Sulgostowska). Warsaw: Institute of Archaeology and Ethnology, Polish Academy of Sciences, pp. 29-39.

Biagi, P., Kazi, M. M., Madella, M. and Ottomano, C. 1998-2000. Excavations at the Late (Upper) Palaeolithic site of Ziarat Pir Shaban 2 (ZPS2) in the Rohri Hills, Sindh, Pakistan. Origini, 22: 111-33.

Blandford, W. T. 1880. The geology of Western Sind. Memoirs of the Geological Survey of India, 17: $1-210$.

Burnes, A. 1834. Travels into Bokhara Being the Account of a Journey from India to Cabool, Tartary and Persia; also, Narrative of a Voyage on the Indus, from the Sea to Lahore, with Presents from the King of Great Britain; Performed under the Orders of the Supreme Government of India, in the Years 1831, 1832, and 1833. London: John Murray.

Casal, J.-M. 1964. Fouilles d'Amri, 2 vols. Paris: Klincksieck.

Childe, V. G. 1926. The Aryans: A Study of Indo-European Origins. London: Kegan Paul, Trench, Trubner.

Childe, V. G. 1928. The Most Ancient East: The Oriental Prelude to European Prehistory. London: Kegan Paul, Trench, Trubner.

Childe, V. G. 1934. New Light on the Most Ancient East: The Oriental Prelude to European Prehistory. London: Kegan Paul, Trench, Trubner.

Cleland, J. H. 1987. Lithic analysis and culture process in the Indus region. In Studies in the Archaeology of India and Pakistan (ed. J. Jacobson). Warminster: Aris \& Phillips, pp. 91-116.

Cleuziou, S. 2004. Pourquoi si tard? Nous avons pris un autre chemin: l'Arabie des chasseurscueilleurs de l'Holocene au début de l'Age du Bronze. In Aux marges des grands foyers du Néolithique: Périphéries débitrices ou créatrices? (ed. J. Guilaine). Paris: Errance, pp. 123-48.

Cousens, H. 1998. The Antiquities of Sind with Historical Outline. Karachi: Department of Culture Government of Sindh.

Dales, G. F. and Lipo, C. P. 1992. Explorations on the Makran Coast, Pakistan: A Search for Paradise. Contributions of the Archaeological Research Facility, 50. Berkeley: University of California at Berkeley.

Desse, J. and Desse-Berset, N. 2005. Les Ichthyophages du Makran (Bélouchistan, Pakistan). Paléorient, 31(1): 86-96.

de Terra D. and Paterson, T. T. 1939. The Ice Age in the Indian Subcontinent and Associated Human Cultures with Special Reference to Jammu, Kashmir, Ladakh, Sind, Liddar and Central \& Peninsular India. Washington, DC: Carnegie Institute.

Dikshit, K. N. 1939. Prehistoric Civilization of the Indus Valley: Sir William Meyer Lectures, 1935. Karachi, Indus Publications.

Dutta, K., Bhushan, R. and Somayajulu, B. L. K. 2001. $\Delta$ R correction values for the northern Indian Ocean. Radiocarbon, 43(2A): 483-88.

Eggermont, P. H. L. 1975. Alexander's Campaigns in Sind and Balochistan and the Siege of the Brahmin Town of Harmatelia. Orientalia Lovaniensa Analecta, 3. Leuven: Leuven University Press.

Evans, J. 1886. On some flint-cores from the Indus, Upper Scinde. The Geological Journal, 28: 433-35. 
Fairservis, W. A. Jr. 1982. Allahdino: an excavation of a small Harappan site. In Harappan Civilization: A Contemporary Perspective (ed. G. Possehl). Warminster: Aris \& Phillips, pp. 107-12.

Flam, L. 1984. The palaeogeography and prehistoric settlement patterns of the Lower Indus Valley, Sind, Pakistan. In Studies in the Archaeology and Palaeoanthropology of South Asia (eds K. A. R. Kennedy and G. L. Possehl). New Delhi, Bombay and Calcutta: Oxford University Press and IBH Publishing, pp. 77-82.

Flam, L. 1987. Recent explorations in Sind: paleogeography, regional ecology, and prehistoric settlement patterns (ca. 4000-2000 B.C.). In Studies in the Archaeology of India and Pakistan (ed. J. Jacobson). Warminster: Aris \& Phillips, pp. 65-89.

Flam, L. 1996. Ghazi Shah excavations 1985-1987: an interim report. Pakistan Archaeology, 28: 131-58.

Flam, L. 2006. Archaeological research in Western Sindh: the Khirtar Mountains, Sindh Kohistan, and excavations at Ghazi Shah. In Sindh: Past, Present \& Future (ed. F. Hussain). Karachi: University of Karachi B.C.C.T. and Press, pp. 152-83.

Giosan, L., Constantinescu, S., Clift, P. D., Tabrez, A. R., Danish, M. and Inam, A. 2006. Recent morphodynamics of the Indus delta shore and shelf. Continental Shelf Research, 26: 1668-84.

Gordon, D. H. 1950. The stone industries of the Holocene in India and Pakistan. Ancient India, 6: 64-90.

Halim, M. A. and Vidale, M. 1984. Kilns, bangles and coated vessels: ceramic production in close containers at Moenjodaro. In Interim Reports, 1 (eds M. Jansen and G. Urban). Rome: Joint RWTH/IsMEO Moenjodaro Research Project, pp. 63-97.

Harvey, M. D. and Schumm, S. A. 1999. Indus River dynamics and the abandonment of Mohenjo Daro. In The Indus River: Biodiversity, Resources, Humankind (eds A. Meadows and P. S. Meadows). Karachi: Oxford University Press, pp. 332-48.

Hoffman, M. A. and Cleland, J. H. 1977. Excavations at Allahdino II: The Lithic Industry. Papers of the Allahdino Expedition, 2. New York.

Inam, A., Clift, P. D., Giosan, L., Tabrez, A. R., Tahir, M., Rabbani, M. M. and Danish, M., 2007. The geographic, geological and oceanographic setting of the Indus River. In Large Rivers: Geomorphology and Management (ed. A. Gupta). London: Wile, pp. 333-46.

Jarrige, J-F. 2004. Le Néolithique des frontières indo-iraniennes: Mehrgarh. In Aux marges des grands foyers du Néolithique: Périphéries débitrices ou créatrices? (ed. J. Guilaine). Paris: Errance, pp. 31-62.

Kenoyer, J. M. 1991. The Indus Valley tradition of Pakistan and Western India. Journal of World Prehistory, 5(4): 331-86.

Khan, A. R. 1979a. Ancient settlements in Karachi region. In Studies in Geomorphology and Prehistory of Sind (ed. A. R. Khan). Special issue of Grassroots, 3(2): 1-23.

Khan, A. R. 1979b. Palaeolithic sites discovered in the Lower Sind and their significance in the prehistory of the country. In Studies in Geomorphology and Prehistory of Sind (ed. A. R. Khan). Special issue of Grassroots, 3(2): 80-6.

Khan, A. R. 1979c. River piracy and diversion in Karachi Basin. In Studies in Geomorphology and Prehistory of Sind (ed. A. R. Khan). Special issue of Grassroots, 3(2): 47-60.

Lahiri, N. 1992. The Archaeology of Indian Trade Routes (up to c. 200 BC). Delhi: Oxford University Press.

Lahiri, N. 2005. Finding Forgotten Cities: How the Indus Civilisation was Discovered. New Delhi: Paul Press.

Lambeck, K. 1996. Shoreline reconstructions for the Persian Gulf since the last Glacial Maximum. Earth and Planetary Science Letters, 142: 43-57. 
Lambrick, H. T. 1942. Amateur excursions in archaeology, Lower Sind - 1941. The Journal of the Sind Historical Society, 6(2): 104-12.

Lambrick, H. T. 1986. Sind: A General Introduction. Hyderabad and Jamshoro: Sindhi Adabi Board.

Law, R., Baqri, S. R. H., Mahmood, K. and Khan, M. 2002-2003. First results of neutron activation study comparing Rohri Hills chert to other sources in Pakistan and archaeological samples from Harappa. Ancient Sindh, 7: 7-25. Khairpur.

Leonardi, G. 1988. New problems of surface archaeology: sampling in HR East area of Moenjodaro (Pakistan). In Interim Reports, 3 (eds M. Jansen and M. Tosi). Rome: Joint RWTH/IsMEO Moenjodaro Research Project, pp. 7-71.

Mackay, E. J. H. ( 1937-8). Further Excavations at Mohenjo-daro, 2 vols. Delhi: Government of India.

Maifreni, A. 1995. A photographic survey and photo interpretation in the Rohri Hills (SindhPakistan). Ancient Sindh, 2: 41-54.

Majumdar, N. C. 1981. Explorations in Sind: Being a Report of the Exploratory Survey Carried out during the Years 1927-28, 1929-30 and 1930-31. Memoirs of the Archæological Survey of India, 48. Karachi: Indus Publications.

Marshall, J. (Sir) 1931. Extent of the Indus Civilization. In Mohenjo-daro and the Indus Civilization being an Official Account of Archaeological Excavations at Mohenjo-daro Carried out by the Government of India Between the Years 1922 and 1927, Vol. 1 (ed. J. Marshall). London: Arthur Probsthain, pp. 91-101.

Negrino, F. and Starnini, E. 1995. A preliminary report of the 1994 excavations on the Rohri Hills (Sindh - Pakistan). Ancient Sindh, 2: 55-80.

Negrino, F. and Starnini, E. 1996. Notes on the technology of the pre-core and blade-core preparation in Harappan times: observations from Site ZPS3 (Rohri Hills, Sindh, Pakistan). Ancient Sindh, 3: 105-16.

Negrino, F., Ottomano, C., Starnini, E. and Veesar, G. M. 1996. Excavations at Site 862 (Rohri Hills, Sind, Pakistan): a preliminary report of the 1995 and 1997 campaigns. Ancient Sindh, 3: 67-104.

Panhwar, M. H. 1964. Ground Water in Hyderabad \& Khairpur Divisions. Hyderabad: Directorate of Agriculture, Hyderabad Region.

Piggott, S. 1950. Prehistoric India. London: Cassell.

Possehl, G. L. 1997. The transformation of the Indus Civilization. Journal of World Prehistory, 11(4): 425-72.

Possehl, G. L. 2002. The Indus Civilization: A Contemporary Perspective. Walnut Creek, CA: Altamira.

Pracchia, S., Tosi, M. and Vidale, M. 1985. On the type, distribution and extent of craft industries at Mohenjo-Daro. In South Asian Archaeology 1983 (ed. M. Taddei). Series Minor XXIII(1). Naples: Istituto Universitario Orientale, Dipartimento di Studi Asiatici, pp. 207-248.

Rao, S. R. 1985. Lothal: A Harappan Port Town 1955-62, Vol. 2. Calcutta: Archaeological Survey of India.

Ray, H. P. 2008. Colonial Archaeology in South Asia: The Legacy of Sir Mortimer Wheeler. New Delhi: Oxford University Press.

Reimer, P. J. and Reimer, R. W. 2001. A marine reservoir correction database and on-line interface. Radiocarbon, 43(2A): 461-3.

Robson, E. I. 1967. Arrian, Anabasis Alexandri Books I-IV, Vol. 1. London: Loeb Classical Library. Romm, J. (ed.) 2010. The Landmark Arrian: The Campaigns of Alexander. New York: Pantheon. 
Sanlaville, P. and Dalongeville, R. 2005. L'évolution des espaces littoraux du Golfe Persique et du Golfe d'Oman depuis la phase finale de la transgression post-glaciale. Paléorient, 31(1): 9-26.

Schoff, W. H. 1974. The Periplus of the Erythrean Sea: Travel and Trade in the Indian Ocean by a Merchant of the First Century. New Delhi: Oriental Books Reprint Corporation.

Snead, R. E. 1966. Physical Geography Reconnaissance: Las Bela Coastal Plain, West Pakistan. Louisiana State University Studies, Coastal Studies Series 13.

Snead, R. E. 1967. Recent morphological changes along the coast of West Pakistan. Annals of the Association of American Geographers, 57(3): 550-65.

Snead, R. E. 1969. Physical Geography Reconnaissance: West Pakistan Coastal Zone. Albuquerque: University of New Mexico Publications in Geography, 1.

Starnini, E. and Biagi, P. 2006. Excavations at the Harappan flint quarry 862 on the Rohri Hills (Sindh, Pakistan). In Stone Age - Mining Age, Bochum (eds G. Körlin and G. Weisgerber). Special issue of Der Anschnitt, 19: 195-202.

Stein, A. (Sir) 1943. On Alexander's route into Gedrosia: an archaeological tour in Las Bela. The Geographical Journal, 102(5-6): 193-226.

Todd, K. R. U. and Paterson, T. T. 1947. A flint microlithic industry from Karachi, India. Paper submitted for publication to the Proceedings of the Prehistoric Society (unpublished).

Tosi, M., Bondioli, L. and Vidale, M. 1984. Craft activity areas and surface survey at Moenjodaro: complementary procedures for the revaluation of a restricted site. In Interim Reports, 1 (eds M. Jansen and G. Urban). Rome: Joint RWTH/IsMEO Moenjodaro Research Project, pp. 9-37.

Vidale, M. 1992. Produzione Artigianale Protostorica: Etnoarcheologia e Archeologia. Saltuarie del Laboratorio del Piovego, 4. Dipartimento di Scienze dell'Antichità, Università degli Studi di Padova.

Vidale, M. 2000. The Archaeology of Indus Crafts: Indus Craftspeople and Why We Study Them. Reports and Memoirs, Series Minor, 4. Rome: IsIAO.

Vita-Finzi, C. and Copeland, L. 1980. Surface finds from Iranian Makran. Iran, 18: 149-55.

Wheeler, M. 1950. 5000 Years of Pakistan: An Archaeological Outline. London: Johnson.

Wheeler, M. 1976. My Archaeological Mission to India and Pakistan. London: Thames \& Hudson.

Wilhelmy, H. 1968. Indusdelta und Rann of Kutch. Erdkunde, 22(3): 177-91.

Paolo Biagi is Full Professor of Prehistory and Protohistory at Ca' Foscari University, Venice. He has carried out research and excavations in Northern Italy, Sardinia, Transylvania, Ukraine, Western Macedonia, Oman, Kuwait and Sindh (Pakistan). His main interests concern the prehistory of the Balkan Peninsula, Arabian Sea coasts, Indus Valley and their radiocarbon chronology. 